\title{
Assessment of the use of plant protection products on vegetable crops in Poland in years 2017-2018
}

\author{
Ocena stosowania środków ochrony roślin w uprawach warzyw \\ w Polsce w latach 2017-2018
}

\author{
Jolanta Szymczak*, Joanna Kicińska, Artur Miszczak
}

\section{Summary}

The aim of the study was to evaluate the use of plant protection products in vegetable crops in Poland based on the analysis of active substances residues. Vegetable samples were collected from all over Poland in 2017-2018 as a part of the official inspection. The analysis was carried out to assess the number of samples without pesticide residues, with residues at a level not exceeding the MRL, exceeding the MRL and containing residues of plant protection products, not approved for use in Poland on a specific vegetable crop. A total of 907 vegetable samples were tested - 442 in 2017 and 465 in 2018, for the presence of 422 and 437 active substances and their metabolites, respectively. It was found that $26.5 \%$ samples of the total number of samples in 2017 and $20.2 \%$ samples in 2018 , did not contain residues of tested plant protection products. The pesticide residues were detected in the remaining samples. Among the samples containing plant protection products residues - $25.1 \%$ samples in 2017 and $22.8 \%$ samples in 2018, contained substances not approved for use in a specific vegetable crop. MRL exceedances were found in 4.7\% samples in 2017 and in 6.0\% samples in 2018.

Key words: vegetables, pesticide residues, MRL exceedances, unauthorised use of pesticides

\section{Streszczenie}

Celem opracowania była ocena stosowania środków ochrony roślin w uprawach warzywnych w Polsce na podstawie analizy pozostałości substancji czynnych. Próbki warzyw były pobierane z terenu całej Polski w latach 2017-2018 w ramach kontroli urzędowej. Analizę przeprowadzono pod kątem oceny liczby próbek bez pozostałości pestycydów oraz z pozostałościami na poziomie nieprzekraczającym NDP, przekraczającym NDP oraz zawierających pozostałości środków ochrony roślin, których użycie w danej uprawie warzyw jest w Polsce niedozwolone. Łącznie przebadano 907 próbek - 442 w roku 2017 i 465 w roku 2018 analizując obecność odpowiednio: 422 i 437 substancji czynnych i ich metabolitów. Stwierdzono, że 26,5\% ogólnej liczby próbek w 2017 roku i 20,2\% w 2018 roku nie zawierało pozostałości środków ochrony roślin w badanym zakresie. W pozostałych próbkach wykryto obecność substancji czynnych, wśród których 25,1\% próbek w roku 2017 i 22,8\% w roku 2018 zawierała substancje niedozwolone do stosowania w danej uprawie. Przekroczenia NDP stwierdzono w 4,7\% próbek warzyw w 2017 roku i w 6,0\% w 2018 roku.

Słowa kluczowe: warzywa, pozostałości pestycydów, przekroczenie NDP, niedozwolone zastosowanie pestycydów

Instytut Ogrodnictwa

Konstytucji 3 Maja 1/3, 96-100 Skierniewice

*corresponding author: Jolanta.Szymczak@inhort.pl

ORCID: 0000-0002-9090-7604 


\section{Wstęp / Introduction}

Najnowsze badania naukowe dowodzą, że podstawę codziennej diety powinny stanowić warzywa i owoce. Produkty te dostarczają wielu cennych i niezbędnych dla prawidłowego funkcjonowania naszego organizmu składników oraz przyczyniają się do ograniczenia ryzyka rozwoju niektórych chorób. $Z$ tego właśnie względu, w 2016 roku Instytut Żywności i Żywienia dokonał zmian w Piramidzie Zdrowego Żywienia i Aktywności Fizycznej uznając warzywa i owoce za podstawę naszej diety i przesuwając je do podstawy piramidy żywieniowej tuż nad aktywność fizyczną (Broszura 2016). Instytut Żywności i Żywienia rekomenduje, aby w naszym codziennym menu znalazło się minimum $400 \mathrm{~g}$ warzyw i owoców podzielonych na 5 porcji. Według danych Głównego Urzędu Statystycznego (GUS 2018, 2019) wynika, że warzywa stanowią grupę artykułów żywnościowych, których miesięczne spożycie na jedną osobę w polskim gospodarstwie domowym jest największe i w roku 2017 wynosiło 8,24 kg (w tym ziemniaków 3,16 kg), a w roku $2018-7,92 \mathrm{~kg}$ (w tym ziemniaków 2,97 kg), podczas gdy spożycie owoców w tym okresie wyniosło odpowiednio: $3,64 \mathrm{~kg}$ i $3,75 \mathrm{~kg}$. Przy tak dużym spożyciu warzyw ważne jest zapewnienie polskim konsumentom bezpiecznych produktów. Nieprawidłowe lub nadmierne stosowanie środków ochrony roślin (ś.o.r.) niesie za sobą niebezpieczeństwo obecności ich pozostałości i może stanowić zagrożenie dla bezpieczeństwa konsumentów i środowiska naturalnego. Dlatego ważna jest systematyczna kontrola prawidłowości stosowania i ocena pozostałości ś.o.r. w płodach rolnych. W Polsce obowiązek sprawowania kontroli nad stosowaniem ś.o.r. w produkcji roślinnej, w tym prowadzenia badań pod kątem pozostałości substancji czynnych tych środków, wynika zarówno z prawa krajowego, w szczególności ustawy o środkach ochrony roślin (Ustawa 2013), jak i przepisów Unii Europejskiej (UE), w szczególności rozporządzenia WE Nr 1107/2009 (Rozporządzenie 2009). Nadzór nad tą kontrolą sprawuje Państwowa Inspekcja Ochrony Roślin i Nasiennictwa (PIORiN).

Zakład Badania Bezpieczeństwa Żywności (ZBBŻ) Instytutu Ogrodnictwa w Skierniewicach od kilkunastu lat współpracuje z PIORiN, prowadząc badania pozostałości ś.o.r. w ramach urzędowej kontroli. Kontrola ta ma na celu sprawdzenie prawidłowości stosowania ś.o.r. pod kątem:

- zgodności z rozporządzeniem w sprawie najwyższych dopuszczalnych poziomów pozostałości pestycydów w żywności i paszy pochodzenia roślinnego i zwierzęcego oraz na ich powierzchni (Rozporządzenie 2005),

- zgodności z rozporządzeniem dotyczącym wprowadzania do obrotu środków ochrony roślin (Rozporządzenie 2009),

- zgodności z ustawą o środkach ochrony roślin (Ustawa 2013).

Właściwe stosowanie ś.o.r. powinno opierać się o aktualnie zarejestrowane środki wyszczególnione w rejestrze środków ochrony roślin dopuszczonych do obrotu i stosowania zamieszczonym na stronach Ministerstwa Rolnictwa i Rozwoju Wsi (Wykaz 2020).

Celem badań była ocena stosowania ś.o.r. w uprawach warzywnych w latach 2017-2018 pod kątem zgodności z obowiązującymi przepisami prawa oraz zapobieganie wprowadzaniu do obrotu warzyw stwarzających zagrożenie dla zdrowia człowieka. Badania prowadzono w ramach zadania 2.5 „Badanie pozostałości środków ochrony roślin w ramach urzędowej kontroli ich stosowania" Programu Wieloletniego na lata 2015-2020 pod nazwą: „Działania na rzecz poprawy konkurencyjności i innowacyjności sektora ogrodniczego z uwzględnieniem jakości i bezpieczeństwa żywności oraz ochrony środowiska naturalnego" (Uchwała 2015).

\section{Materiały i metody / Materials and methods}

\section{Pobieranie próbek warzyw / Sampling of vegetables}

Próbki warzyw zostały pobrane przez inspektorów Wojewódzkich Inspektoratów Ochrony Roślin i Nasiennictwa (WIORiN) zgodnie z harmonogramem zróżnicowanym dla poszczególnych upraw, województw i lat badań. Próbki były pobierane w sposób określony w rozporządzeniu Ministra Rolnictwa i Rozwoju Wsi w sprawie pobierania próbek roślin, produktów roślinnych lub przedmiotów do badań na obecność pozostałości środków ochrony roślin (Rozporządzenie 2013).

Ogólną liczbę próbek warzyw dostarczonych przez poszczególne województwa w latach 2017 i 2018 przedstawiono $\mathrm{w}$ tabeli 1., a liczbę próbek poszczególnych gatunków warzyw na rysunku 1. Łącznie do badań dostarczono 907 próbek warzyw - 442 w roku 2017 i 465 w roku 2018. Biorąc pod uwagę gatunki warzyw (rys. 1) największą liczbę próbek przesłanych do badań stanowiła marchew (161 próbek) i kapusta pekińska (134 próbki) oraz pietruszka korzeniowa (91 próbek), cebula (81 próbek) i seler korzeniowy (71 próbek).

\section{Analiza pozostałości ś.o.r. / Pesticide residues analysis}

Badania przeprowadzone w ZBBŻ objęły w roku 2017 - 421, a w 2018 - 436 substancji czynnych ś.o.r., ich izomerów i metabolitów oznaczanych w tzw. metodzie wielopozostałościowej (PN-EN 15662 2008) przy użyciu dwóch wysoce selektywnych technik chromatograficznych: chromatografii gazowej i cieczowej, sprzężonych z tandemową spektrometrią mas (GC-MS/MS i LC-MS/MS) oraz pozostałości fungicydów ditiokarbaminianowych oznaczanych grupowo jako disiarczek węgla (PN-EN 12396-2 2002) przy użyciu techniki chromatografii gazowej z detekcją spektrometrii mas (GC-MS).

W przypadku metody wielopozostałościowej (Multi Residue Method) próbki do oznaczeń chromatogaficz- 
Tabela 1. Liczba próbek warzyw dostarczonych przez WIORiN z poszczególnych województw na terenie Polski i zbadanych w Zakładzie Badania Bezpieczeństwa Żywności na obecność pozostałości środków ochrony roślin w latach 2017-2018

Table 1. Quantity of vegetable samples provided by WIORiN from individual provinces in Poland and tested in Food Safety Laboratory for the presence of residues of plant protection products in 2017-2018

\begin{tabular}{c|c|c|c}
\hline \multirow{2}{*}{$\begin{array}{c}\text { Lp. } \\
\text { No. }\end{array}$} & $\begin{array}{c}\text { Województwo } \\
\text { Voivodeship }\end{array}$ & \multicolumn{2}{c}{$\begin{array}{c}\text { Liczba próbek warzyw } \\
\text { w poszczególnych latach } \\
\text { Quantity of vegetable samples } \\
\text { in individual years }\end{array}$} \\
\cline { 3 - 4 } & & 2017 & 2018 \\
\hline 1 & dolnośląskie & 9 & 14 \\
\hline 2 & kujawsko-pomorskie & 27 & 28 \\
\hline 3 & lubelskie & 21 & 48 \\
\hline 4 & lubuskie & 13 & 11 \\
\hline 5 & łódzkie & 103 & 74 \\
\hline 6 & małopolskie & 31 & 71 \\
\hline 7 & mazowieckie & 99 & 71 \\
\hline 8 & opolskie & 14 & 8 \\
\hline 9 & podkarpackie & 9 & 15 \\
\hline 10 & podlaskie & 10 & 11 \\
\hline 11 & pomorskie & 7 & 12 \\
\hline 12 & śląskie & 11 & 8 \\
\hline 13 & świętokrzyskie & 44 & 46 \\
\hline 14 & warmińsko-mazurskie & 9 & 7 \\
\hline 15 & wielkopolskie & 23 & 29 \\
\hline 16 & zachodniopomorskie & 12 & 12 \\
\hline Ogółem - Total & 442 & 465 \\
\hline & & & \\
\hline
\end{tabular}

nych przygotowywano w oparciu o metodę ekstrakcji QuEChERS. Polegała ona na izolacji i podziale składników próbki w układzie ciecz-ciecz z użyciem acetonitrylu, a następnie oczyszczeniu ekstraktu z wykorzystaniem metody dyspersyjnej ekstrakcji do fazy stałej (d-SPE - dispersive solid phase extraction). Metoda ta została po raz pierwszy opublikowana w 2003 roku (Anastassiades i wsp. 2003) i w 2004 roku włączona do zakresu badań ZBBŻ. Ekstrakty analizowano przy użyciu:

- chromatografu gazowego Agilent Technologies 7890A wyposażonego w detektor masowy 7000 Triple Quad GC/MS, autosampler 7693, rozdział na kolumnie kapilarnej DB-5MS, 30,0 $\mathrm{m} \times 250 \mu \mathrm{m} \times 0,25 \mu \mathrm{m}$,

- chromatografu cieczowego Agilent Technologies 1200 Series wyposażonego w detektor masowy 6410 Triple Quad LC/MS, autosampler 1200 Series, rozdział na kolumnie Eclipse Plus C18, $100 \mathrm{~mm} \times 2,1 \mathrm{~mm}, 1,8 \mu \mathrm{m}$.

Identyfikację i analizę ilościową analitów objętych poszczególnymi technikami chromatograficznymi przeprowadzono techniką monitorowania reakcji wielokrotnych (multiple reaction monitoring).
Pozostałości fungicydów ditiokarbaminianowych oznaczano metodą opartą na pomiarze disiarczku węgla $\left(\mathrm{CS}_{2}\right)$ uwolnionego $\mathrm{z}$ tkanki roślinnej podczas ogrzewania w gazoszczelnym naczyniu z kwasem chlorowodorowym i chlorkiem cyny (II), a następnie zaadsorbowaniu gazowego $\mathrm{CS}_{2}$ do fazy ciekłej - izooktanowej i ilościowym oznaczeniu za pomocą chromatografu gazowego (PN-EN 12396-2 2002; Česnik i Gregorčič 2006). Analizę próbki przeprowadzono przy użyciu chromatografu gazowego Agilent Technologies 6850 Series GC System wyposażonego w detektor masowy 5973N Mass Selectivity Detector i autosampler 6850 Automatic Liquid Sampler. Rozdział substancji przeprowadzono na kolumnie kapilarnej DB-35MS, 30,0 $\mathrm{m} \times 250 \mu \mathrm{m} \times 0,25 \mu \mathrm{m}$.

Metody użyte do badań były objęte zakresem akredytacji ZBBŻ (Nr akredytacji AB 757). Procedury walidacyjne i kontrola jakości zastosowanych metod analitycznych spełniały wymagania dokumentu SANTE/11813/2017 (SANTE 2017). W okresie objętym badaniami ZBBŻ potwierdził swoje kompetencje w zakresie oznaczania pestycydów w żywności pochodzenia roślinnego uzyskując satysfakcjonujące wyniki w międzynarodowych badaniach biegłości, organizowanych przez Laboratoria Referencyjne Unii Europejskiej (EUPT-FV, EUPT-CF, EUPT-SRM). Na podstawie uzyskanych wyników ZBBŻ został zaklasyfikowany do najwyższej kategorii (klasa A) wśród laboratoriów Unii Europejskiej.

\section{NDP UE / MRL EU}

Oznaczone stężenia substancji czynnych porównano z najwyższymi dopuszczalnymi poziomami pozostałości ś.o.r. (NDP) obowiązującymi w Polsce i Unii Europejskiej (Rozporządzenie 2005), uwzględniając wytyczne dokumentu SANTE (2017) odnośnie podejmowania decyzji przy stwierdzaniu zgodności/niezgodności z wymaganiami. Jeżeli oznaczona zawartość pozostałości ś.o.r. po odjęciu niepewności rozszerzonej pomiaru wynoszącej 50\% (poziom ufności 95\%, współczynnik rozszerzenia 2) była mniejsza lub równa wartości NDP, wówczas stwierdzano zgodność $\mathrm{z}$ wymaganiami. $\mathrm{W}$ pozostałych przypadkach, gdy wartość ta była wyższa od NDP, stwierdzano niezgodność z wymaganiami i zawartość pozostałości interpretowano jako przekroczenie NDP. Kontrola prawidłowości stosowania ś.o.r. była prowadzona $\mathrm{w}$ oparciu o aktualizowany rejestr ś.o.r. dopuszczonych do obrotu i stosowania (Wykaz 2020). Stwierdzone przekroczenia NDP oraz nieprawidłowe zastosowania ś.o.r. w danej uprawie podlegały niezwłocznym zgłoszeniom do odpowiednich oddziałów PIORiN. W rezultacie dalszych urzędowych działań mogły one podlegać zgłoszeniom w ramach europejskiego systemu Rapid Alert System for Food and Feed (RASFF), zgodnie z ustawą o bezpieczeństwie żywności i żywienia (Ustawa 2006). 


\section{Wyniki i dyskusja / Results and discussion}

W roku 2017 przebadano 442 próbki różnych gatunków warzyw na obecność 422 substancji czynnych i ich metabolitów jako pozostałości po ś.o.r. Stwierdzono, że 117 próbek, co stanowiło $26,5 \%$ ogólnej liczby próbek, nie zawierało pozostałości ś.o.r. w badanym zakresie (tab. 2). W pozostałych próbkach wykryto obecność substancji, przy czym w 304 próbkach $(68,8 \%)$ pozostałości ś.o.r. nie przekraczały NDP, natomiast w 21 próbkach $(4,8 \%)$ wykryto przekroczenia NDP. Z kolei w roku 2018 przebadano 465 próbek warzyw na obecność 437 substancji czynnych. Wyniki analiz wykazały, że 94 próbki $(20,2 \%)$ nie zawierały pozostałości pestycydów w badanym zakresie, natomiast pozostałe zawierały pozostałości na różnym poziomie. Większość z nich -343 próbki $(73,8 \%)$ zawierały pozostałości, których stężenia nie przekraczały NDP, wartości NDP zostały przekroczone w 28 próbkach, co stanowiło 6,0\% ogólnej liczby przebadanych próbek (tab. 2). Podobne wyniki, dotyczące przekroczeń NDP pozostałości ś.o.r. w warzywach, podają statystyki z badań żywności opracowane przez Europejski Urząd ds. Bezpieczeństwa Żywności (EFSA). Raporty opracowane na podstawie wyników badań prowadzonych w ramach skoordynowanego monitoringu UE i monitoringów krajowych państw członkowskich UE wskazują, że próbki warzyw z pozostałościami przekroczającymi NDP stanowily 5,0\% w roku 2017 i 6,4\% w roku 2018 (Scientific Report 2019, 2020). Porównując przedstawione wyniki badań można wnioskować, że odsetek próbek polskich upraw warzywnych z pozostałościami ś.o.r. przekraczającymi NDP jest zbliżona do obserwowanej w UE, jak również wzrost liczby tych próbek w roku 2018 w stosunku do roku 2017.

Spośród wykrywanych pozostałości ś.o.r. najliczniejszą grupą związków były fungicydy (43 substancje w 2017 roku i 46 substancji w 2018 roku) i insektycydy (31 substancji w 2017 roku i 37 substancji w 2018 roku). W badanych próbkach warzyw wykrywano również pozostałości herbicydów - 13 substancji w 2017 roku i 9 substancji w 2018 roku (rys. 2). Nowacka i wsp. (2020a) również najliczniej wykrywali pozostałości fungicydów (40) i insektycydów (31), a najmniej herbicydów (6) badając pozostałości ś.o.r. w płodach rolnych, natomiast Kaczyński i wsp. (2018) analizując pozostałości ś.o.r. w warzywach korzeniowych potwierdzili obecność 11 związków, w tym sześciu fungicydów, czterech herbicydów i jednego z grupy insektycydów.

Uprawami, w których największy procent próbek zawierał pozostałości ś.o.r. przekraczające NDP była nać pietruszki - 33,0\% i kapusta pekińska - 15,3\% (rys. 3). W brokułach i koprze pozostałości te kształtowały się odpowiednio na poziomie: $9,0 \%$ i $8,9 \%$, a w pasternaku, porze i selerze: $6,3 \%, 6,6 \%$ i 7,0\%. Pozostałości pestycydów przekraczające NDP stwierdzono również w kapuście brukselskiej $(4,7 \%)$ i kapuście głowiastej $(3,2 \%)$ oraz w korzeniu pietruszki $(4,3 \%)$ i marchwi $(2,4 \%)$. Uprawą warzywną nie zawierającą pozostałości ś.o.r. w badanym zakresie była cukinia. W pozostałych gatunkach warzyw wykryte substancje czynne nie przekraczały NDP (rys. 3). Kaczyński i wsp. (2018) analizując pozostałości ś.o.r. (426 substancji czynnych) w warzywach korzeniowych w roku 2017 stwierdzili przekroczenia NDP tylko w próbkach korzenia pietruszki. Warzywami korzeniowymi bez pozostałości były - burak ćwikłowy i pasternak, natomiast pozostałe (marchew, rzodkiewka i seler) zawierały pozostałości ś.o.r. poniżej NDP. Analizując raporty EFSA (Scientific Report 2019, 2020) można stwierdzić, że spośród badanych upraw warzyw to nać pietruszki niesie największe ryzyko obecności pozostałości ś.o.r. przekraczające NDP. Przedstawione tam wyniki badań wskazują, że 16,9\% próbek przebadanych

Tabela 2. Liczba i procent próbek bez pozostałości pestycydów oraz z pozostałościami na poziomie poniżej NDP, powyżej NDP i zawierających substancje niezarejestrowane dla danej uprawy warzyw w latach 2017-2018

Table 2. Quantity and percentage of samples without pesticide residues and with residues below the MRL, above the MRL and containing substances not approved for the vegetable crops in 2017-2018

\begin{tabular}{|c|c|c|c|c|}
\hline \multirow{3}{*}{$\begin{array}{l}\text { Rodzaj próbek } \\
\text { Type of samples }\end{array}$} & \multicolumn{4}{|c|}{ Udział próbek - The share of samples } \\
\hline & \multicolumn{2}{|c|}{2017} & \multicolumn{2}{|c|}{2018} \\
\hline & $\begin{array}{c}\text { liczba } \\
\text { quantity }\end{array}$ & $\begin{array}{c}\text { procent } \\
\text { percentage }\end{array}$ & $\begin{array}{c}\text { liczba } \\
\text { quantity }\end{array}$ & $\begin{array}{c}\text { procent } \\
\text { percentage }\end{array}$ \\
\hline Próbki bez pozostałości - Samples without residues & 117 & 26,5 & 94 & 20,2 \\
\hline $\begin{array}{l}\text { Próbki z pozostałościami } \leq \mathrm{NDP} \text { - Samples with residues } \leq \mathrm{MRL} \\
\text { w tym - including } \\
\text { Próbki zawierające niedozwolone substancje - Samples containing } \\
\text { unpermitted substances }\end{array}$ & $\begin{array}{l}304 \\
94\end{array}$ & 68,8 & 83 & $\begin{array}{l}73,8 \\
17,9\end{array}$ \\
\hline $\begin{array}{l}\text { Próbki z pozostałościami }>\text { NDP }- \text { Samples with residues }>\text { MRL } \\
\text { w tym - including } \\
\text { Próbki zawierające niedozwolone substancje - Samples containing } \\
\text { unpermitted substances }\end{array}$ & 21 & $\begin{array}{l}4,7 \\
3,8\end{array}$ & 28 & 6,0 \\
\hline $\begin{array}{l}\text { Łącznie próbki spełniające normy prawne } \\
\text { Total samples that meet legal standards }\end{array}$ & 327 & 74,0 & 354 & 76,1 \\
\hline
\end{tabular}


w krajach UE w roku 2017 i 13,0\% w roku 2018 zawierało pozostałości pestycydów na poziomie przekraczającym NDP. Kolejnymi uprawami warzywnymi w krajach UE, zawierającymi znaczny odsetek próbek z pozostałościami ś.o.r. powyżej NDP były szczypiorek (12,6\% w roku 2017 i $8,6 \% \mathrm{w}$ roku 2018$)$ oraz seler $(9,0 \% \mathrm{w}$ roku 2017 i $10,8 \%$ w roku 2018). Badania przeprowadzone w ZBBŻ nie wykazały przekroczeń NDP pestycydów oznaczonych w szczypiorku, jak również w papryce, w przypadku której średnio 5,7\% próbek w roku 2017 i 6,4\% w roku 2018 w krajach UE nie spełniało wymagań NDP dla wykrytych pestycydów (Scientific Report 2019, 2020).

Na 907 przebadanych w sumie próbek warzyw w 49 próbkach stwierdzono przekroczenia NDP 17 substancji czynnych, wśród których dominował chloropiryfos. Jego dopuszczalne poziomy pozostałości zostały przekroczone w 30 próbkach różnych gatunków warzyw, z czego najwięcej (17 próbek) w kapuście pekińskiej (tab. 3). W przypadku chloropiryfosu w 2016 roku obniżono NDP dla jego pozostałości, m.in. w kapuście pekińskiej do poziomu 0,01 mg/kg (Rozporządzenie 2016), co mogło powodować niedostosowanie się producentów warzyw do nowych wymagań. Nowacka i Hołodyńska-Kulas (2020a) stwierdziły, że nowelizacja przepisów dotyczących chloropiryfosu wpłynęła na wzrost przekroczeń NDP w krajowych płodach rolnych w latach 2016-2017 w porównaniu z latami 2014-2015 (Nowacka i wsp. 2020b). Również problem chloropiryfosu sygnalizowali Kaczyński i wsp. (2018), którzy wykryli jego nieprawidłowe zastosowanie w marchwi, pietruszce i rzodkiewce. W 2018 roku nastąpiło obniżenie NDP dla chloropiryfosu do poziomu $0,01 \mathrm{mg} / \mathrm{kg}$ dla kolejnych produktów rolnych (Rozporządzenie 2018), a od dnia 16 kwietnia 2020 r. wprowadzono zakaz stosowania tej substancji w Unii Europejskiej (Rozporządzenie 2020). Badania prowadzone w przyszłych latach dowiodą, czy problem z obecnością pozostałości chloropiryfosu został zażegnany. Kolejnymi substancjami czynnymi, powodującymi najczęstsze przekroczenia dopuszczalnych dla danych

Tabela 3. Przekroczenia najwyższych dopuszczalnych poziomów pozostałości (NDP) w badanych uprawach w latach 2017-2018

Table 3. Residues exceeding maximum residue levels (MRLs) in the tested crops in 2017-2018

\begin{tabular}{|c|c|c|c|c|c|c|}
\hline \multirow{2}{*}{$\begin{array}{c}\text { Substancja czynna } \\
\text { Active substance }\end{array}$} & \multirow{2}{*}{$\begin{array}{l}\text { Uprawa } \\
\text { Crop }\end{array}$} & \multirow{2}{*}{$\begin{array}{c}\mathrm{GO}^{1} \\
\mathrm{LOQ} \\
{[\mathrm{mg} / \mathrm{kg}]}\end{array}$} & \multirow{2}{*}{$\begin{array}{c}\mathrm{NDP}^{2} \\
\mathrm{MRL} \\
{[\mathrm{mg} / \mathrm{kg}]}\end{array}$} & \multicolumn{3}{|c|}{$\begin{array}{l}\text { Przekroczenia NDP } \\
\text { MRLs exceedances }\end{array}$} \\
\hline & & & & $\begin{array}{l}\text { liczba } \\
\text { quantity }\end{array}$ & $\begin{array}{c}\text { procent } \\
\text { percentage }\end{array}$ & $\begin{array}{c}\text { zakres pozostałości } \\
\text { range of residues } \\
{[\mathrm{mg} / \mathrm{kg}]}\end{array}$ \\
\hline 1 & 2 & 3 & 4 & 5 & 6 & 7 \\
\hline \multicolumn{7}{|c|}{2017} \\
\hline Bupirimate & pietruszka naciowa - parsley leaf & 0,005 & 0,05 & 1 & 33,3 & 0,70 \\
\hline Chlorothalonil & kapusta pekińska - chinese cabbage & 0,005 & 0,01 & 1 & 2,2 & 0,041 \\
\hline Chlorpyrifos & kapusta pekińska - chinese cabbage & 0,005 & 0,01 & 6 & 13,3 & $0,023-0,29$ \\
\hline Chlorpyrifos & koper-dill & 0,005 & 0,05 & 1 & 8,3 & 0,23 \\
\hline Chlorpyrifos & marchew - carrots & 0,005 & 0,1 & 1 & 1,0 & 0,22 \\
\hline Chlorpyrifos & pietruszka korzeniowa - parsley root & 0,005 & 0,05 & 2 & 3,4 & $0,13-0,14$ \\
\hline Chlorpyrifos & seler korzeniowy - celeriac & 0,005 & 0,05 & 1 & 1,8 & 0,13 \\
\hline Dimethoate & kapusta pekińska - chinese cabbage & 0,001 & 0,01 & 1 & 2,2 & 0,10 \\
\hline Mandipropamid & por-leek & 0,001 & 0,01 & 1 & 6,7 & 0,074 \\
\hline Piraclostrobin & koper-dill & 0,005 & 2 & 1 & 8,3 & 6,3 \\
\hline Prochloraz & kapusta pekińska - chinese cabbage & 0,005 & 0,05 & 1 & 2,2 & 0,25 \\
\hline Propamocarb & seler - celeriac & 0,005 & 0,09 & 1 & 1,8 & 0,19 \\
\hline Propiconazole & marchew - carrots & 0,005 & 0,01 & 1 & 1,0 & 0,022 \\
\hline Propiconazole & pietruszka korzeniowa - parsley root & 0,005 & 0,01 & 1 & 1,7 & 0,028 \\
\hline Propiconazole & seler korzeniowy - celeriac & 0,005 & 0,01 & 2 & 2,6 & $0,021-0,031$ \\
\hline Tebuconazole & kapusta pekińska - chinese cabbage & 0,005 & 0,02 & 1 & 2,2 & 1,70 \\
\hline Tetraconazole & marchew - carrots & 0,005 & 0,02 & 1 & 1,0 & 0,041 \\
\hline \multicolumn{7}{|c|}{2018} \\
\hline Chlorothalonil & brokuł - broccoli & 0,005 & 0,01 & 2 & 6,1 & $0,051-1,76$ \\
\hline Chlorpyrifos & brokuł - broccoli & 0,005 & 0,01 & 4 & 12,1 & $0,036-0,32$ \\
\hline Chlorpyrifos & kapusta brukselska - brussels sprouts & 0,005 & 0,01 & 1 & 7,1 & 0,22 \\
\hline
\end{tabular}


Tabela 3. Przekroczenia najwyższych dopuszczalnych poziomów pozostałości (NDP) w badanych uprawach w latach $2017-2018$ - cd. Table 3. Residues exceeding maximum residue levels (MRLs) in the tested crops in 2017-2018 - continued

\begin{tabular}{l|c|c|c|c|c|c}
\hline \multicolumn{1}{c|}{1} & 2 & 3 & 4 & 5 & 6 & 7 \\
\hline Chlorpyrifos & kapusta głowiasta - head cabbage & 0,005 & 0,01 & 1 & 5,0 & 0,15 \\
\hline Chlorpyrifos & kapusta pekińska - chinese cabbage & 0,005 & 0,01 & 11 & 12,4 & $0,021-1,81$ \\
\hline Chlorpyrifos & koper - dill & 0,005 & 0,05 & 1 & 2,2 & 0,28 \\
\hline Chlorpyrifos & pietruszka korzeniowa - parsley root & 0,005 & 0,05 & 1 & 3,0 & 0,13 \\
\hline Dimethoate & brokuł - broccoli & 0,001 & 0,02 & 1 & 3,0 & 0,38 \\
\hline Dimethoate & kapusta pekińska - chinese cabbage & 0,001 & 0,01 & 3 & 3,4 & $0,066-0,53$ \\
\hline Dithocarbamates & koper - dill & 0,01 & 0,1 & 1 & 2,2 & 0,56 \\
\hline Methomyl & brokul - broccoli & 0,01 & 0,01 & 1 & 3,0 & 0,094 \\
\hline Omethoate & brokuł - broccoli & 0,0025 & 0,01 & 1 & 3,0 & 0,048 \\
\hline Omethoate & kapusta głowiasta - head cabbage & 0,0025 & 0,01 & 1 & 5,0 & 0,025 \\
\hline Omethoate & kapusta pekińska - chinese cabbage & 0,0025 & 0,01 & 2 & 2,2 & $0,021-0,048$ \\
\hline Pendimethalin & koper - dill & 0,005 & 0,05 & 1 & 2,2 & 0,16 \\
\hline Pyrimethanil & kapusta pekińska - chinese cabbage & 0,005 & 0,01 & 1 & 1,1 & 0,058 \\
\hline Pyrimethanil & seler korzeniowy - celeriac & 0,005 & 0,01 & 1 & 6,7 & 0,030 \\
\hline Propiconazole & marchew - carrots & 0,005 & 0,01 & 1 & 1,5 & 0,036 \\
\hline Propiconazole & pasternak - parsnips & 0,005 & 0,01 & 1 & 10,0 & 0,030 \\
\hline Tebuconazole & brokuł - broccoli & 0,005 & 0,15 & 1 & 3,0 & 0,70 \\
\hline Thiamethoxam & kapusta brukselska - brussels sprouts & 0,005 & 0,02 & 1 & 7,1 & 0,14 \\
\hline
\end{tabular}

${ }^{1} \mathrm{GO}$ - granica oznaczalności - LOQ - limit of quantification

${ }^{2} \mathrm{NDP}$ - najwyższy dopuszczalny poziom - MRL - Maximum Residue Level

upraw poziomów pozostałości były propikonazol i dimetoat. Należy przy tym zauważyć, że propikonazol podobnie jak chloropiryfos, to substancja niedozwolona do stosowania w badanych uprawach warzywnych. Dimetoat z kolei, nie został zarejestrowany do stosowania w uprawie kapusty pekińskiej, gdzie został wykryty i to w stężeniu przekraczającym jego dopuszczalny poziom. Propikonazol i dimetoat to substancje zarejestrowane w uprawie zbóż. Substancje zastosowane niezgodnie $\mathrm{z}$ aktualnym rejestrem ś.o.r. zostały wykryte w znacznej części badanych próbek, tzn. w 25,1\% w 2017 roku i 22,8\% w 2018 roku. W obu latach badań wykryto w sumie 72 substancje czynne niedozwolone do stosowania w uprawie badanych gatunków warzyw (tab. 4). Wykryte substancje niedozwolone stanowiły dodatkowo główne źródło przekroczeń NDP. W ponad 80\% próbek, gdzie stwierdzono przekroczenia NDP (80,9\% w 2017 roku i 81,7\% w 2018 roku), były to substancje nieposiadające rejestracji dla danej uprawy. Podobne wyniki uzyskała Nowacka i Hołodyńska-Kulas (2020a), które wykazały, że w latach 2016-2017 nieprawidłowe stosowanie ś.o.r. w płodach rolnych dotyczyło również 72 substancji.

Tabela 4. Wykryte substancje czynne niedozwolone do stosowania w badanych uprawach warzyw na terenie Polski w latach 2017-2018 Table 4. Detected active substances not approved for use in the tested vegetable crops in Poland in 2017-2018

\begin{tabular}{|c|c|c|}
\hline \multirow{2}{*}{$\begin{array}{l}\text { Substancja czynna } \\
\text { Active substance }\end{array}$} & \multicolumn{2}{|c|}{ Uprawa-Crop } \\
\hline & 2017 & 2018 \\
\hline 1 & 2 & 3 \\
\hline Acetamiprid & $\begin{array}{l}\text { koper }-\operatorname{dill}(1)^{*} \\
\text { rukola }- \text { rucola }(1)\end{array}$ & koper - dill (3) \\
\hline Anthraquinone & koper - dill (1) & koper - dill (1) \\
\hline Azoxystrobin & $\begin{array}{c}\text { koper }- \text { dill (3) } \\
\text { pasternak - parsnip (1) } \\
\text { pietruszka korzeniowa - parsley root (18) } \\
\text { rzodkiewka - radish (2) }\end{array}$ & $\begin{array}{c}\text { koper }- \text { dill (2) } \\
\text { pasternak - parsnip (3) } \\
\text { pietruszka korzeniowa }- \text { parsley root (13) }\end{array}$ \\
\hline
\end{tabular}


Tabela 4. Wykryte substancje czynne niedozwolone do stosowania w badanych uprawach warzyw na terenie Polski w latach 2017-2018 - cd. Table 4. Detected active substances not approved for use in the tested vegetable crops in Poland in 2017-2018 - continued

\begin{tabular}{|c|c|c|}
\hline 1 & 2 & 3 \\
\hline Bifenthrin & pietruszka naciowa - parsley leaf (1) & koper - dill (1) \\
\hline Boscalid & kapusta pekińska - chinese cabbage (4) & $\begin{array}{l}\text { fasola }- \text { beans (1) } \\
\text { kapusta pekińska }- \text { chinese cabbage (3) }\end{array}$ \\
\hline Clomazon & - & koper - dill (1) \\
\hline Chlorantraniliprole & - & kapusta pekińska - chinese cabbage (1) \\
\hline Chlorpyrifos & $\begin{array}{c}\text { chrzan - horseradish (1) } \\
\text { groch - peas (1) } \\
\text { kapusta pekińska - chinese cabbage (9) } \\
\text { koper - dill (6) } \\
\text { marchew - carrots (15) } \\
\text { pasternak - parsnips (1) } \\
\text { pietruszka korzeniowa - parsley root (13) } \\
\text { pietruszka naciowa - parsley leaf (2) } \\
\text { rukola - rucola (2) } \\
\text { rzodkiewka - radish (4) } \\
\text { sałata - lettuce }(1) \\
\text { seler - celeriac }(7) \\
\text { szpinak - spinach }(2)\end{array}$ & $\begin{array}{c}\text { kapusta pekińska - chinese cabbage (34) } \\
\text { kminek - black caraway (2) } \\
\text { koper - dill (26) } \\
\text { marchew - carrots (7) } \\
\text { pasternak - parsnips (1) } \\
\text { pietruszka korzeniowa - parsley root (8) } \\
\text { seler - celeriac (2) }\end{array}$ \\
\hline Chlorpyrifos-methyl & - & marchew - carrots $(1)$ \\
\hline Clothianidin & - & kapusta brukselska - brussels sprouts (1) \\
\hline Cypermethrin & $\begin{array}{l}\text { kapusta pekińska - chinese cabbage (4) } \\
\text { marchew - carrots (2) } \\
\text { pietruszka korzeniowa - parsley root (1) }\end{array}$ & $\begin{array}{c}\text { kapusta pekińska - chinese cabbage (5) } \\
\text { koper - dill (2) } \\
\text { marchew }- \text { carrots (1) } \\
\text { seler }- \text { celeriac (1) }\end{array}$ \\
\hline Cyprodinil & koper - dill (1) & - \\
\hline Cyproconazole & seler - celeriac $(1)$ & - \\
\hline DDT & $\begin{array}{c}\text { chrzan }- \text { horseradish }(2) \\
\text { koper }- \text { dill }(2) \\
\text { marchew }- \text { carrots }(3) \\
\text { pietruszka korzeniowa - parsley root (4) }\end{array}$ & $\begin{array}{c}\text { chrzan }- \text { horseradish }(1) \\
\text { koper }- \text { dill (2) } \\
\text { marchew }- \text { carrots }(1) \\
\text { pietruszka korzeniowa }- \text { parsley root }(2)\end{array}$ \\
\hline DEET & seler - celeriac $(1)$ & $\begin{array}{l}\text { jarmuż }- \text { kales }(1) \\
\text { koper }- \text { dill }(2)\end{array}$ \\
\hline Dimethoate & $\begin{array}{c}\text { jarmuż }- \text { kales }(1) \\
\text { kapusta pekińska }- \text { chinese cabbage (5) }\end{array}$ & kapusta pekińska - chinese cabbage (13) \\
\hline Dichlorobenzamide & - & koper - dill (1) \\
\hline Diphenylamine & - & kminek - black caraway (1) \\
\hline Dimethomorph & $\begin{array}{l}\text { bób - broad bean }(1) \\
\text { koper - dill (1) }\end{array}$ & $\begin{array}{l}\text { kapusta pekińska - chinese cabbage (1) } \\
\text { koper - dill (2) } \\
\text { pietruszka korzeniowa - parsley root (1) }\end{array}$ \\
\hline Dithiocarbamates & $\begin{array}{c}\text { kapusta brukselska - brussels sprouts (6) } \\
\text { koper - dill (1) } \\
\text { rukola - rucola (5) }\end{array}$ & koper - dill (9) \\
\hline Epoxiconazole & $\begin{array}{l}\text { koper }- \text { dill }(1) \\
\text { marchew - carrots }(1) \\
\text { seler }- \text { celeriac }(1)\end{array}$ & $\begin{array}{c}\text { koper }- \text { dill (1) } \\
\text { pietruszka korzeniowa - parsley root (1) } \\
\text { seler - celeriac (1) }\end{array}$ \\
\hline Esfenvalerate & - & kapusta brukselska - brussels sprouts (1) \\
\hline Ethofumesate & seler - celeriac $(1)$ & - \\
\hline Ethirimol & pietruszka naciowa - parsley leaf (1) & - \\
\hline Famoxadone & - & pomidor - tomato (1) \\
\hline Fenpropimorph & seler - celeriac $(1)$ & - \\
\hline Fenvalerate & $\begin{array}{c}\text { kapusta pekińska - chinese cabbage (2) } \\
\text { seler - celeriac }(2)\end{array}$ & $\begin{array}{l}\text { kapusta pekińska - chinese cabbage (1) } \\
\text { koper - dill (1) }\end{array}$ \\
\hline
\end{tabular}


Tabela 4. Wykryte substancje czynne niedozwolone do stosowania w badanych uprawach warzyw na terenie Polski w latach 2017-2018 - cd. Table 4. Detected active substances not approved for use in the tested vegetable crops in Poland in 2017-2018 - continued

\begin{tabular}{|c|c|c|}
\hline 1 & 2 & 3 \\
\hline Flonicamid & - & pomidor - tomato (1) \\
\hline Floupyram & seler - celeriac (1) & - \\
\hline Fludioxonil & koper - dill (1) & kapusta pekińska - chinese cabbage (2) \\
\hline Fluopicolide & $\begin{array}{c}\text { pasternak - parsnips (1) } \\
\text { pietruszka naciowa - parsley leaf (1) } \\
\text { pomidor - tomato (1) } \\
\text { por - leek (1) } \\
\text { rzodkiewka - radish (1) } \\
\text { seler - celeriac }(3) \\
\text { szpinak - spinach (1) } \\
\end{array}$ & $\begin{array}{c}\text { kapusta głowiasta - head cabbage }(1) \\
\text { marchew - carrots }(1) \\
\text { papryka - sweet pepper }(1) \\
\text { pomidor - tomato }(3)\end{array}$ \\
\hline Fluopyram & rukola - rucola (2) & - \\
\hline Flutriafol & - & kminek - black caraway (1) \\
\hline Fluvalinate & kapusta brukselska - brussels sprouts (1) & - \\
\hline Imidacloprid & $\begin{array}{l}\text { kapusta brukselska - brussels sprouts (1) } \\
\text { kapusta pekińska - chinese cabbage (1) }\end{array}$ & - \\
\hline Indoxacarb & brokuk - broccoli (1) & - \\
\hline Iprodion & pietruszka korzeniowa - parsley root (1) & - \\
\hline Captan & $\begin{array}{c}\text { kapusta pekińska - chinese cabbage (1) } \\
\text { koper - dill (1) }\end{array}$ & $\begin{array}{c}\text { koper }- \text { dill }(1) \\
\text { marchew }- \text { carrots }(1)\end{array}$ \\
\hline Carbendazim & $\begin{array}{c}\text { kapusta pekińska - chinese cabbage (8) } \\
\text { koper - dill (2) }\end{array}$ & $\begin{array}{c}\text { kalarepa - kohlrabi (1) } \\
\text { kapusta pekińska - chinese cabbage (9) } \\
\text { koper - dill (2) }\end{array}$ \\
\hline Lambdacyhalothrin & $\begin{array}{c}\text { kapusta pekińska - chinese cabbage (1) } \\
\text { rukola - rucola (1) }\end{array}$ & kapusta pekińska - chinese cabbage (1) \\
\hline Lenacil & por - leek $(1)$ & - \\
\hline Lindane & - & koper - dill (1) \\
\hline Linuron & szczypiorek - chives (1) & kapusta pekińska - chinese cabbage (1) \\
\hline Mandipropamid & por - leek (1) & - \\
\hline Metalaxyl & $\begin{array}{c}\text { kapusta pekińska - chinese cabbage (5) } \\
\text { pietruszka korzeniowa - parsley root (1) } \\
\text { rzodkiewka - radish (1) } \\
\text { seler - celeriac (1) } \\
\text { szpinak - spinach (1) }\end{array}$ & $\begin{array}{c}\text { kapusta pekińska - chinese cabbage (3) } \\
\text { koper - dill (2) }\end{array}$ \\
\hline Metamitron & szpinak - spinach (2) & - \\
\hline Methomyl & - & kapusta pekińska - chinese cabbage (1) \\
\hline Metribuzin & seler - celeriac $(1)$ & kapusta głowiasta - head cabbage (1) \\
\hline Oxyfluorophen & koper - dill (1) & koper - dill (1) \\
\hline Omethoate & - & kapusta pekińska - chinese cabbage (4) \\
\hline Pencycuron & marchew - carrots $(1)$ & $\begin{array}{c}\text { fasola }- \text { bean }(1) \\
\text { pietruszka korzeniowa - parsley root (1) } \\
\text { seler - celeriac (1) }\end{array}$ \\
\hline Pendimethalin & szpinak - spinach (2) & $\begin{array}{c}\text { kapusta pekińska - chinese cabbage (1) } \\
\text { papryka - sweet pepper (1) } \\
\text { pomidor - tomato }(1)\end{array}$ \\
\hline Picoxystrobin & kapusta brukselska - brussels sprouts (1) & - \\
\hline Pyraclostrobin & kapusta pekińska - chinese cabbage (3) & kapusta pekińska - chinese cabbage (2) \\
\hline Pyrimethanil & koper - dill (1) & $\begin{array}{c}\text { kapusta pekińska - chinese cabbage (2) } \\
\text { koper - dill (1) } \\
\text { seler - celeriac (1) }\end{array}$ \\
\hline Pirimicarb & kapusta pekińska - chinese cabbage (1) & - \\
\hline
\end{tabular}


Tabela 4. Wykryte substancje czynne niedozwolone do stosowania w badanych uprawach warzyw na terenie Polski w latach 2017-2018 - cd. Table 4. Detected active substances not approved for use in the tested vegetable crops in Poland in 2017-2018 - continued

\begin{tabular}{|c|c|c|}
\hline 1 & 2 & 3 \\
\hline Prochloraz & $\begin{array}{c}\text { kapusta pekińska - chinese cabbage (1) } \\
\text { pasternak - parsnips (1) }\end{array}$ & - \\
\hline Procymidone & - & marchew - carrots $(1)$ \\
\hline Propamocarb & $\begin{array}{c}\text { koper }- \text { dill }(1) \\
\text { pietruszka naciowa - parsley leaf }(1) \\
\text { por - leek (1) } \\
\text { rzodkiewka - radish (3) } \\
\text { seler - celeriac (3) }\end{array}$ & $\begin{array}{c}\text { kapusta pekińska - chinese cabbage (2) } \\
\text { koper - dill (1) }\end{array}$ \\
\hline Propiconazole & $\begin{array}{c}\text { koper }- \text { dill (1) } \\
\text { marchew }- \text { carrots (1) } \\
\text { pasternak }- \text { parsnips (1) } \\
\text { pietruszka korzeniowa }- \text { parsley root (1) } \\
\text { seler }- \text { celeriac }(3)\end{array}$ & $\begin{array}{c}\text { koper - dill (1) } \\
\text { marchew - carrots }(1) \\
\text { pasternak - parsnips }(1)\end{array}$ \\
\hline Prosulfocarb & koper - dill (1) & koper - dill (9) \\
\hline Prothioconazole & pietruszka korzeniowa - parsley root (1) & - \\
\hline Spinosad & kapusta pekińska - chinese cabbage (1) & kapusta pekińska - chinese cabbage (2) \\
\hline Spiroxamine & $\begin{array}{l}\text { marchew }- \text { carrots (2) } \\
\text { pietruszka korzeniowa - parsley root (1) }\end{array}$ & pomidor - tomato (1) \\
\hline Tebuconazole & $\begin{array}{c}\text { seler - celeriac (7) } \\
\text { szczypiorek - chives (1) }\end{array}$ & $\begin{array}{c}\text { kminek - black caraway (1) } \\
\text { koper - dill (2) }\end{array}$ \\
\hline Terbutylazine & koper - dill (1) & koper - dill (4) \\
\hline Tetraconazole & $\begin{array}{c}\text { marchew }- \text { carrots (1) } \\
\text { pietruszka korzeniowa - parsley root (2) } \\
\text { seler - celeriac (1) }\end{array}$ & $\begin{array}{l}\text { kapusta pekińska - chinese cabbage (2) } \\
\text { marchew - carrots (1) } \\
\text { pietruszka korzeniowa - parsley root (1) }\end{array}$ \\
\hline Thiacloprid & $\begin{array}{l}\text { bób - broad beans (1) } \\
\text { jarmuż - kales (1) } \\
\text { seler - celeriac }(1)\end{array}$ & papryka - sweet pepper (1) \\
\hline Thiamethoxam & koper - dill (1) & kapusta brukselska - brussels sprouts (1) \\
\hline Thiophanate-methyl & kapusta pekińska - chinese cabbage (2) & kapusta pekińska - chinese cabbage (3) \\
\hline Trifloxystrobin & kapusta pekińska - chinese cabbage (1) & $\begin{array}{c}\text { kapusta pekińska - chinese cabbage (1) } \\
\text { papryka - sweet pepper (1) }\end{array}$ \\
\hline Trifluralin & seler - celeriac $(1)$ & czosnek - garlic (1) \\
\hline
\end{tabular}

*w nawiasach podano liczbę próbek zawierających substancję niedozwoloną - in brackets are given the quantity of samples containing the unpermitted substance

Podsumowując oba lata badań można stwierdzić, że 26,0\% próbek warzyw w roku 2017 i 23,9\% w roku 2018 nie spełniało wymagań prawnych ze względu na pozostałości ś.o.r. (przekroczenia NDP, substancje niedozwolone). Wyniki te są alarmujące, bowiem świadczą o niestosowaniu się znacznej części polskich producentów warzyw do aktualnych wymagań prawnych dotyczących stosowania ś.o.r.

\section{Wnioski / Conclusions}

1. Próbki warzyw niezawierające pozostałości ś.o.r. w badanym zakresie stanowiły $26,5 \%$ ogólnej liczby przebadanych próbek w 2017 roku i 20,2\% w 2018 roku.

2. Próbki warzyw zawierające pozostałości ś.o.r. na poziomie nieprzekraczającym NDP stanowiły 68,8\% ogólnej liczby przebadanych próbek w 2017 roku i 73,8\% w 2018 roku.

3. Próbki warzyw zawierające pozostałości ś.o.r. na poziomie przekraczającym NDP stanowiły 4,7\% ogólnej liczby przebadanych próbek w 2017 roku i 6,0\% w 2018 roku.

4. Wśród próbek zawierających pozostałości ś.o.r. znaczna ich część, tj. 25,1\% w 2017 roku i 22,8\% w 2018 roku zawierała substancje czynne niedozwolone do stosowania w danej uprawie warzyw.

5. Stwierdzono, że $26,0 \%$ próbek warzyw w 2017 roku i $23,9 \%$ w 2018 roku nie spełniało wymagań prawnych ze względu na pozostałości ś.o.r. 


\section{Literatura / References}

Anastassiades M., Lehotay S.J., Stajnbaher D., Schenck F.J. 2003. Fast and easy multiresidue method employing acetonitrile extraction/ partitioning and "dispersive solid-phase extraction" for the determination of pesticide residues in produce. Journal of AOAC International 86 (2): 412-431. DOI: 10.1093/jaoac/86.2.412

Broszura Instytutu Żywności i Żywienia im. prof. dra med. Aleksandra Szczygła. 2016. Piramida Zdrowego Żywienia i Aktywności Fizycznej. Piramida opracowana w Instytucie Żywności i Żywienia w 2016 r. pod kierunkiem prof. dra hab. med. Mirosława Jarosza. http://www.izz.waw.pl/attachments/article/7/Piramida [dostęp: 16.09.2020].

Česnik H.B., Gregorčič A. 2006. Validation of the method for the determination of dithiocarbamates and thiuram disulphide on apple, lettuce, potato, strawberry and tomato matrix. Acta Chimica Slovenica 53: 100-104.

GUS 2018. Mały Rocznik Statystyczny Polski. Główny Urząd Statystyczny, Warszawa. ISSN 1640-3630. http://www.stat.gov.pl [dostęp: 16.09.2020].

GUS 2019. Mały Rocznik Statystyczny Polski. Główny Urząd Statystyczny, Warszawa. ISSN 1640-3630. http://www.stat.gov.pl [dostęp: 16.09.2020].

Kaczyński P., Hrynko I., Rutkowska E., Mojsak P., Szabuńko J., Łozowicka B. 2018. Optymalizacja wielopozostałościowej metody oznaczania pozostałości pestycydów w warzywach korzeniowych. [Optimization of the multiresidue method for the determination of pesticide residues in root vegetables]. Progress in Plant Protection 58 (1): 13-21. DOI: 10.14199/ppp-2018-001

Nowacka A., Hołodyńska-Kulas A. 2020a. Pozostałości środków ochrony roślin w płodach rolnych (2016-2017). [Pesticide residues in agricultural crops (2016-2017)]. Progress in Plant Protection 60 (3): 201-231. DOI: 10.14199/ppp-2020-023

Nowacka A., Hołodyńska-Kulas A., Drożdżyński D., Przewoźniak M., Pszczolińska K., Łozowicka B., Kaczyński P. 2020b. Pozostałości środków ochrony roślin w płodach rolnych (2014-2015). [Pesticide residues in agricultural crops (2014-2015)]. Progress in Plant Protection 60 (2): 81-104. DOI: 10.14199/ppp-2020-010

PN-EN 12396-2. 2002. Żywność o niskiej zawartości tłuszczu - Oznaczanie pozostałości ditiokarbaminianów i disiarczku tiuramu. Część 2: Metoda z wykorzystaniem chromatografii gazowej, 9 ss.

PN-EN 15662. 2008. Żywność pochodzenia roślinnego. Oznaczanie pozostałości pestycydów metodą GC-MS i/lub LC-MS(MS) po uprzedniej ekstrakcji i rozdziale acetonitrylem oraz oczyszczaniu metodą dyspersyjnej SPE. Metoda QuEChERS, $81 \mathrm{ss.}$

Rozporządzenie (WE) nr 396/2005 Parlamentu Europejskiego i Rady z dnia 23 lutego 2005 r. w sprawie najwyższych dopuszczalnych poziomów pozostałości pestycydów w żywności i paszy pochodzenia roślinnego i zwierzęcego oraz na ich powierzchni, zmieniające Dyrektywę Rady 91/414/EWG (Dz. Urz. L 70 z 16.03.2006 r. z późn. zm.). http://eurl-lex.europa.eu/legal-content/PL [dostęp: 22.01.2020].

Rozporządzenie Parlamentu Europejskiego i Rady (WE) Nr 1107/2009 z dnia 21 października 2009 r. dotyczące wprowadzania do obrotu środków ochrony roślin i uchylające dyrektywy Rady 79/117/EWG i 91/414/EWG. https://eur-lex.europa.eu/legal-content/PL [dostęp: 22.01.2020].

Rozporządzenie Ministra Rolnictwa i Rozwoju Wsi z dnia 27 listopada 2013 r. w sprawie pobierania próbek roślin, produktów roślinnych lub przedmiotów do badań na obecność pozostałości środków ochrony roślin. 2013. Dz. U. z 2013 r., poz. 154.

Rozporządzenie Komisji (UE) 2016/60 z dnia 19 stycznia 2016 r. zmieniające załączniki II i III do rozporządzenia (WE) nr 396/2005 Parlamentu Europejskiego i Rady w odniesieniu do najwyższych dopuszczalnych poziomów pozostałości chloropiryfosu w określonych produktach oraz na ich powierzchni. 2016. Dz. Urz. UE L 14 z 21.01.2016 r., str. 1-17.

Rozporządzenie Komisji (UE) 2018/686 z dnia 4 maja 2018 r. zmieniające załączniki II i III do rozporządzenia (WE) nr 396/2005 Parlamentu Europejskiego i Rady w odniesieniu do najwyższych dopuszczalnych poziomów pozostałości chloropiryfosu, chloropiryfosu metylowego i triklopyru w określonych produktach lub na ich powierzchni. 2018. Dz. Urz. UE L 121 z 16.05.2018 r., str. 30-62.

Rozporządzenie Wykonawcze Komisji (UE) 2020/18 z dnia 10 stycznia 2020 r. w sprawie nieodnowienia zatwierdzenia substancji czynnej chloropiryfos, zgodnie z rozporządzeniem Parlamentu Europejskiego i Rady (WE) nr 1107/2009 dotyczącym wprowadzania do obrotu środków ochrony roślin, oraz w sprawie zmiany załącznika do rozporządzenia wykonawczego Komisji (UE) nr 540/2011. 2020. Dz. Urz. UE L 7 z 13.01.2020 r., str. 14-16.

SANTE/11813/2017. Guidance document on analytical quality control and method validation procedures for pesticide residues and analysis in food and feed. Supersedes SANTE/11945/2015. Implemented by 01/01/2018.

Scientific Report of EFSA 2019. The 2017 European Union report on pesticide residues in food. EFSA Journal $2019 ; 17$ (6): 5743,152 ss. DOI: 10.2903/j.efsa.2019.5743. http://www.efsa.europa.eu/efsajournal [dostęp: 02.10.2020].

Scientific Report of EFSA 2020. The 2018 European Union report on pesticide residues in food. EFSA Journal 2020; 18 (4): 6057,103 ss. DOI: $10.2903 /$ j.efsa.2020.6057. http://www.efsa.europa.eu/efsajournal [dostęp: 02.10.2020].

Uchwała nr 105/2015 Rady Ministrów z dnia 14 lipca 2015 roku w sprawie ustanowienia programu wieloletniego pod nazwą: „Działania na rzecz poprawy konkurencyjności i innowacyjności sektora ogrodniczego z uwzględnieniem jakości i bezpieczeństwa żywności oraz ochrony środowiska naturalnego".

Ustawa z dnia 25 sierpnia 2006 r. o bezpieczeństwie żywności i żywienia (Dz. U. 2019, poz. 1252). http://isap.sejm.gov.pl [dostęp: 16.09.2020].

Ustawa z dnia 8 marca 2013 o środkach ochrony roślin (Dz. U. 2019, poz. 1900). http://isap.sejm.gov.pl [dostęp: 16.09.2020].

Wykaz zezwoleń i decyzji zmieniających. Rejestr Środków Ochrony Roślin. Ministerstwo Rolnictwa i Rozwoju Wsi. 2020. http://www. gov.pl/attachment/345067ad-d4a9-4124-8581-54109fda054c [dostęp: 16.09.2020]. 